\title{
Moisture Sorption Isotherm of Preconditioned Pressure Parboiled Brown Rice
}

Naveen Kumar M and Das SK*

Department of Agricultural and Food Engineering, Indian Institute of Technology, Kharagpur, India

\begin{abstract}
The pressure parboiling of paddy was carried out at $294.204 \mathrm{kPa}$ for $7 \mathrm{~min}$ and preconditioning of brown rice was carried out in fluidized bed dryer at $60-80^{\circ} \mathrm{C}$. The moisture sorption isotherms of pressure parboiled preconditioned brown rice at different salt concentrations $(0,2,3,3.5$ and $4 \%)$ were obtained at $20 \pm 1^{\circ} \mathrm{C}, 25 \pm 1^{\circ} \mathrm{C}$, and $30 \pm 1{ }^{\circ} \mathrm{C}$. The experimental data of sorption isotherm were fitted with some of sorption models (GAB, MGAB, MCPE, MOSE, MHEE, and MHAE models). According to the statistical results, the MGAB model gave the best fit to the experimental sorption data and MHAE model was the least adequate. Sorption isotherm data were used to determine the some thermodynamic functions. The net isosteric heat of sorption was determined from the best fitting equation using the Claussius-Calpeyron equation. The net isosteric heat of sorption decreased with increasing moisture content and increased with increasing salt concentration same trend was observed in entropy of sorption. The spreading pressure increased with increasing water activity and salt concentration and decreased with increasing temperature. The net integral enthalpy decreased with increasing moisture content and increased with increasing salt concentration and reverse trend was observed in integral entropy.
\end{abstract}

Keywords: Brown rice; Equilibrium moisture content; Pressure parboiling; Sorption isotherms; Spreading pressure

\begin{tabular}{|c|c|}
\hline \multicolumn{2}{|c|}{ Notation } \\
\hline $\mathrm{A}, \mathrm{B}, \mathrm{C}$ : & Model constants \\
\hline Am : & Area of water molecule, $1.06 \times 10^{-19} \mathrm{~m}^{2}$ \\
\hline $\mathrm{a}, \mathrm{b}, \mathrm{c}:$ & Constants \\
\hline aw : & Water activity \\
\hline${ }^{\circ} \mathrm{C} \quad:$ & Degree Celsius \\
\hline $\mathrm{CG}, \mathrm{k}_{\mathrm{G}}$ & GAB model constants \\
\hline $\mathrm{K}$ & Boltzmann's constant, $1.38 \times 10^{-23} \mathrm{~J} / \mathrm{K}$ \\
\hline $\mathrm{K}$ & Net isosteric heat constant \\
\hline Mo : & Monolayer moisture content, kg water/ kg dry solids \\
\hline Me : & Equilibrium moisture content, $\mathrm{kg}$ water/ kg dry solids \\
\hline $\mathrm{Mr}:$ & Constant \\
\hline $\mathrm{R}$ & Universal gas constant, $8.314 \mathrm{~kJ} / \mathrm{mol} \mathrm{K}$ \\
\hline $\mathrm{R} 2$ & Coefficient of determination \\
\hline $\mathrm{T}$ & Temperature, $\mathrm{K}$ \\
\hline $\mathrm{Q}_{\mathrm{st}} \quad:$ & Net isosteric heat of sorption, $\mathrm{kJ} / \mathrm{mol}$ \\
\hline $\mathrm{Q}_{\mathrm{o}} \quad:$ & Constant, $\mathrm{kJ} / \mathrm{mol}$ \\
\hline $\mathrm{Q}_{\mathrm{eq}}:$ & Net integral enthalpy, $\mathrm{kJ} / \mathrm{mol}$ \\
\hline$\Delta \mathrm{S}_{\mathrm{eq}}:$ & Net integral entropy, $\mathrm{kJ} / \mathrm{mol} \mathrm{K}$ \\
\hline$\Delta \mathrm{S} \quad:$ & Entropy of sorption, $\mathrm{J} / \mathrm{mol} \mathrm{K}$ \\
\hline$\varnothing$ & Spreading pressure $\left(\mathrm{J} / \mathrm{m}^{2}\right)$ \\
\hline
\end{tabular}

\section{Introduction}

Rice ranks first in terms of global production (603 million tonnes) and used as a staple food for approximately 400 million people in the developing countries [1]. India exports $5 \%$ of the produced rice to the international market and compete with Thailand, Vietnam, and Pakistan. About $10 \%$ of the production of paddy is converted to three rice products, namely, puffed rice, popped rice and flaked rice [2-4]. Among the rice based breakfast cereals, puffed rice is largely demanded product for centuries in India because of its lightness and crispness. When grains such as rice, paddy, corn, gram etc. are heated, vapour pressure of water inside the grain increases. At a certain temperature and after certain duration of time the vapour pressure becomes high which causes expansion of the grain and the process is called puffing $[5,6]$.

Preconditioning of rice is the most critical factor for obtaining highly expanded smooth-surface puffed rice [7]. The process comprises of uniform and slow heating of moisture-salt-conditioned parboiled rice with continuous turning until optimum moisture content of puffing ( $10 \%$ w.b.) is attained. Non uniform heating of grain severely impairs the quality of product with less expansion ratio in addition to rough and blistered surface. Further, puffing efficiency for rice grain depends on several factors, including the nature and concentration of salts diffused into the kernel.

Water activity of food material is determined as the ratio of vapour pressure of water in the food to vapour pressure of pure water at the same temperature. Many food deterioration reactions and the growth of important microorganisms depend on the water activity of the food and water activity is thus an important parameter to predict food stability. In order to determine the storage conditions, it is necessary to know the relationship between the equilibrium moisture content

*Corresonding author: Das SK, Department of Agricultural and Food Engineering, Indian Institute of Technology, Kharagpur, India, Tel: +91 9434068741; E-mail: skd@agfe.iitkgp.ernet.in

Received October 12, 2015; Accepted October 28, 2015; Published November 02,2015

Citation: Naveen Kumar M, Das SK (2015) Moisture Sorption Isotherm of Preconditioned Pressure Parboiled Brown Rice. J Food Process Technol 6: 519. doi:10.4172/2157-7110.1000519

Copyright: (c) 2015 Naveen Kumar M, et al. This is an open-access article distributed under the terms of the Creative Commons Attribution License, which permits unrestricted use, distribution, and reproduction in any medium, provided the original author and source are credited. 
(EMC) in the rice and equilibrium relative humidity of the aeration air at a given temperature. This relationship is described by the sorption isotherm equations [8]. The knowledge of the EMC of rice at several temperatures would allow specifying the storage conditions of rice.

Thermodynamic properties that describe the relationship between water and food are helpful in evaluating the energy requirements in concentration and drying processes and in predicting optimal storage conditions for maximum stability of dry foods. In addition, the evaluation of several thermodynamics properties (enthalpy, entropy, Gibbs free-energy, etc.) is important in the design and optimization of dryers. The isosteric heat of sorption gives a measure of the water-solid binding strength [9]. Knowledge of the differential heat of sorption is useful for designing drying equipment and the understanding of the state of water on food surface [10]. Net integral enthalpy and entropy are used to explain the modes of moisture sorption by foods.

Studies on the sorption behaviour of different varieties of rice were carried out by different authors, jasmine rice crackers, rice [1013], rough rice [14-16], rice kernel components [17], but to the best of my knowledge, no study has been reported on the moisture sorption of preconditioned pressure parboiled brown rice at different salt concentrations. Moisture content of preconditioned rice is the most critical factor for achieving the best quality expanded product. After preconditioning immediately rice has to be puffed otherwise rice should store in moisture proof packaging material to maintain constant moisture content of preconditioned rice. During storage absorption of moisture may deteriorate the puffing quality. Data on MSI of such preconditioned rice will help to evaluate energy required for dehydration and design of packaging systems for storage. Considering these aspects and identifying the existing knowledge gap, the present study has been undertaken with the following objectives.

a) To determine the effect of salt concentration and temperature on the moisture sorption isotherm of preconditioned brown rice.

b) To evaluate several models and compare their goodness of fit.

c) To determine thermodynamic properties and effect of salt concentration on thermodynamic properties such as isosteric heat of sorption, differential enthalpy and entropy, spreading pressure and integral enthalpy and entropy.

\section{Materials and Methods}

\section{Experimental procedure}

IR 1010 variety of pressure parboiled brown rice were collected from local rice mill located at Balichak, West Bengal, India. The paddy was soaked for nearly $8 \mathrm{~min}$ in cold water and then steamed under pressure at $294.204 \mathrm{kPa}$ for $7 \mathrm{~min}$ after that paddy was dried until the moisture content of paddy was reached to $12-14 \%$ (w.b.). After reaching the optimum moisture content the paddy was milled by using rubber roll sheller. $150 \mathrm{ml}$ of water per $\mathrm{kg}$ of rice was mixed with salt $(\mathrm{NaCl})$ at pre-determined rate so as to arrive its concentration in the final dried mass $0-4 \%(\mathrm{w} / \mathrm{w})$. This was followed by tempering for about 6 to 8 hours to facilitate diffusion of both water and salt into the kernel. Preconditioning was carried out using hot air at specific temperature $\left(60-80^{\circ} \mathrm{C}\right)$ using fluidized-bed dryer (Lab dryer, Basic technology Pvt. Ltd, India). This process was continued until the moisture content reaches around $10 \%$ (w.b.). To maintain different moisture contents of sample, preconditioned sample was kept in desiccators containing water to maintain moisture content more than $10 \%$ and silica gel to maintain moisture content lower than $10 \%$. The moisture contents of these samples were checked frequently to obtain required moisture content. After attaining desired moisture contents water activity of pre-conditioned rice samples having different moisture contents were noted at different room temperatures $\left(20 \pm 1^{\circ} \mathrm{C}, 25 \pm 1^{\circ} \mathrm{C}\right.$, and $30 \pm$ $1^{\circ} \mathrm{C}$ ) using water activity meter (Rotronic, HygroLab C1).

\section{Data analysis}

Isotherm models: Experimental moisture sorption data can be described by many sorption models but for this study six isotherm equations were chosen to fit experimental sorption data these are shown in Table 1. Non-linear regression analysis was carried to find out model constants. The extent of fitting of models was evaluated and compared based on three statistical criteria namely coefficient of determination $\left(\mathrm{R}^{2}\right)$, Root mean square error (RMSE), and reduced- $\chi^{2}$.

Root mean square error

$$
\begin{aligned}
& \text { RMSE }=\sqrt{\frac{\sum_{\mathrm{i}=1}^{\mathrm{n}}\left(\mathrm{X}_{\mathrm{obs}, \mathrm{i}}-\mathrm{X}_{\text {model }, \mathrm{i}}\right)^{2}}{\mathrm{n}}} \\
& \text { Reduced }-\chi^{2}=\frac{1}{\mathrm{~d} . \mathrm{f}} \sum \frac{\left(\mathrm{X}_{\mathrm{obs}}-\mathrm{X}_{\text {model }}\right)^{2}}{\sigma^{2}}
\end{aligned}
$$

Where $\mathrm{X}_{\mathrm{obs}}$ is observed values and $\mathrm{X}_{\text {model }}$ is predicted value.

In general, low values of the correlation coefficient, high values of reduced- $\chi^{2}$, and RMSE, means that the model is not able to explain the variation in the experimental data. It is also evident that a single statistical parameter cannot be used to select the best model and the model must always be assessed based on multiple statistical criteria.

Net isosteric heat of sorption: The net isosteric heat of sorption $\left(\mathrm{Q}_{\mathrm{st}}\right)$ (differential) is defined as the total heat of sorption in the food minus the heat of vaporisation of water at the system temperature [18]. This thermal property can be determined from calorimetric measurements or more easily from moisture sorption data. The usual procedure to evaluate isosteric heat of sorption from moisture isotherm is based on a Clasius-Clapeyron equation derived equation [19].

$$
\ln \mathrm{a}_{\mathrm{w}}=-\left(\frac{\mathrm{Q}_{\mathrm{st}}}{\mathrm{R}}\right)\left(\frac{1}{\mathrm{~T}}\right)+\mathrm{k}
$$

\begin{tabular}{|c|c|}
\hline Model & Mathematical expression \\
\hline MGAB & $\mathrm{M}_{\mathrm{e}}=\frac{\mathrm{A} \cdot \mathrm{B} \cdot \mathrm{a}_{\mathrm{w}} \cdot \frac{\mathrm{C}}{\mathrm{T}}}{\left(1-\mathrm{B}_{\mathrm{w}}\right)\left[1-\mathrm{B} \cdot \mathrm{a}_{\mathrm{w}}+\mathrm{a}_{\mathrm{w}} \cdot \mathrm{B} \cdot\left(\frac{\mathrm{C}}{\mathrm{T}}\right)\right.}$ \\
\hline MCPE & $M_{e}=-\frac{1}{C} \ln \left[-\left(\frac{T+B}{A}\right) \ln a_{w}\right]$ \\
\hline MOSE & $M_{e}=(A+B \cdot T) \cdot\left(\frac{a_{w}}{1-a_{w}}\right)^{\frac{1}{C}}$ \\
\hline MHEE & $M_{e}=\left[-\frac{\ln \left(1-a_{w}\right)}{A \cdot(T+B)}\right]^{\frac{1}{c}}$ \\
\hline MHAE & $M_{e}=\left[-\frac{\exp (A+B \cdot T)}{\ln a_{w}}\right]^{\frac{1}{c}}$ \\
\hline GAB & $\frac{\mathrm{m}_{\mathrm{o}} \mathrm{C}_{\mathrm{G}} \mathrm{k}_{\mathrm{G}} \mathrm{a}_{\mathrm{w}}}{\left(1-\mathrm{k}_{\mathrm{G}} \mathrm{a}_{\mathrm{w}}\right)\left(1-\mathrm{k}_{\mathrm{G}} \mathrm{a}_{\mathrm{w}}+\mathrm{k}_{\mathrm{G}} \mathrm{a}_{\mathrm{w}} \mathrm{C}_{\mathrm{G}}\right)}$ \\
\hline
\end{tabular}

Table 1: Mathematical models used to fit experimental data of preconditioned brown rice. 
Citation: Naveen Kumar M, Das SK (2015) Moisture Sorption Isotherm of Preconditioned Pressure Parboiled Brown Rice. J Food Process Technol 6: 519. doi:10.4172/2157-7110.1000519

Page 3 of 9

Where, $\mathrm{R}$ is universal gas constant $\left(8.314 \times 10^{-3} \mathrm{~kJ} \mathrm{~mol}^{-1} \mathrm{~K}^{-1}\right), \mathrm{T}$ is temperature in $\mathrm{K}$ and $\mathrm{k}$ is integral constant. The net isosteric heat of sorption is obtained from the slope of the graph representing $\ln \mathrm{a}_{\mathrm{w}}$ versus $(1 / \mathrm{T})$ at a particular equilibrium moisture content. This is carried out for several equilibrium moisture content determined by the best fitting sorption model. The correlations between $\mathrm{Q}_{\mathrm{st}}$ and $\mathrm{M}_{\mathrm{e}}$ have been reported by various authors $[14,20,21]$.

$$
\begin{aligned}
& Q_{\mathrm{st}}=\mathrm{Q}_{\mathrm{o}} \exp \left(\frac{-\mathrm{M}_{\mathrm{e}}}{\mathrm{M}_{\mathrm{r}}}\right) \\
& \mathrm{Q}_{\mathrm{st}}=\left(\frac{\mathrm{a} \cdot \mathrm{M}_{\mathrm{e}}^{\mathrm{b}}}{\mathrm{c}+\mathrm{M}_{\mathrm{e}}^{\mathrm{d}}}\right)
\end{aligned}
$$

Differential entropy: The differential entropy $(\Delta S)$ of sorption of water at each equilibrium moisture content was obtained by fitting to Equation (5) for various equilibrium moisture contents calculated from the best-fitting equation $[22,23]$.

$$
-\ln \mathrm{a}_{\mathrm{w}}=\frac{\mathrm{Q}_{\mathrm{st}}}{\mathrm{RT}}-\frac{\Delta \mathrm{S}}{\mathrm{R}}
$$

By plotting $\ln a_{w}$ versus $1 / T$, for given equilibrium moisture content, $\Delta S$ was determined from the intercept $(\Delta S / R)$. Many authors discuss about the relationship between $\Delta \mathrm{S}$ and equilibrium moisture content McMinn and Magee [9] gave a power law relationship.

Spreading pressure: It is also called as surface potential, it is the force applied in the surface plane perpendicular to each unit length of edge to keep the surface from spreading. It represents the surface excess free energy [24]. It acts as a second pressure [12] and results in increase in surface tension on bare sorption sites due to the sorbed molecules on them [25]. It was calculated using an analytical procedure

$$
\varnothing=\frac{k T}{A_{m}} \int_{0}^{a_{w}} \frac{m}{a_{w} m_{o}} d a_{w}
$$

Where $\mathrm{k}$ is Boltzman constant $\left(1.38 \times 10^{-23}, \mathrm{~J} / \mathrm{K}\right) ; \mathrm{A}_{\mathrm{m}}$ is the area that occupies one single water molecule at monolayer $\left(1.06 \times 10^{-19} \mathrm{~m}^{2}\right)$. Combine the $\mathrm{GAB}$ equation with the above equation mathematically expressed the $\emptyset$ in the form of GAB equation [26].

$$
\varnothing=\frac{\mathrm{kT}}{\mathrm{A}_{\mathrm{m}}} \ln \left[\frac{1-\mathrm{k}_{\mathrm{G}} \mathrm{a}_{\mathrm{w}}+\mathrm{k}_{\mathrm{G}} \mathrm{C}_{\mathrm{G}} \mathrm{a}_{\mathrm{w}}}{1-\mathrm{k}_{\mathrm{G}} \mathrm{a}_{\mathrm{w}}}\right]
$$

Net integral enthalpy and entropy: The net integral enthalpy $\left(\mathrm{q}_{\mathrm{eg}}\right)$ represents the total energy available to do the work. It gives an indication of the binding strength of water molecules to the solid. The net integral enthalpy is calculated in a similar manner to the isosteric heat but at constant spreading pressure. A plot of $\ln \mathrm{a}_{\mathrm{w}}$ versus $1 / \mathrm{T}$ at a constant spreading pressure $(\varnothing)$ gives the net integral enthalpy from the slope [19].

$$
\mathrm{q}_{\mathrm{eq}}=-\mathrm{R}\left[\frac{\mathrm{d}\left(\ln \mathrm{a}_{\mathrm{w}}\right)}{\mathrm{d} \frac{1}{\mathrm{~T}}}\right] \varnothing
$$

Net integral entropy $\left(\Delta \mathrm{S}_{\mathrm{eq}}\right)$ indicates the degree of disorder and randomness of motion of water molecules [27], it is calculated by using the following equation.

$$
\Delta \mathrm{S}_{\mathrm{eq}}=\frac{-\mathrm{q}_{\mathrm{eq}}}{\mathrm{T}}-\mathrm{R} \ln \left(\mathrm{a}_{\mathrm{w}}\right)^{*}
$$

Where $\left(\mathrm{a}_{\mathrm{w}}\right)^{*}$ is the geometric mean water activity obtained at a constant spreading pressure at different temperatures [9].

\section{Results and Discussions}

\section{Sorption curves}

The moisture sorption isotherms of preconditioned pressure parboiled rice at salt different concentrations at $20 \pm 1^{\circ} \mathrm{C}, 25 \pm 1^{\circ} \mathrm{C}$ and $30 \pm 1^{\circ} \mathrm{C}$ are shown in Figure 1. The results reveal that the water activity
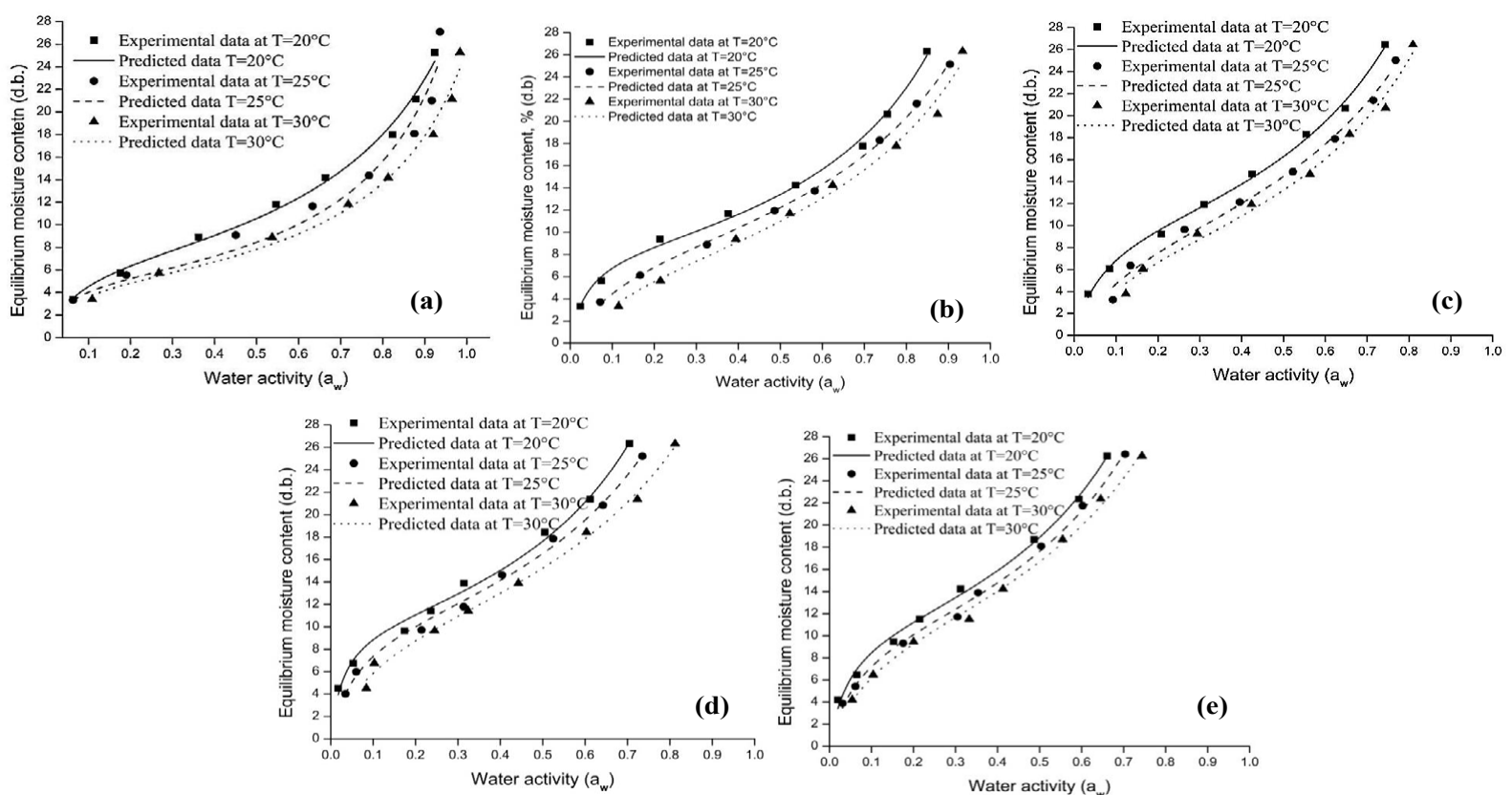

Figure 1: Effect of temperature on moisture sorption isotherm of pre conditioned pressure parboiled brown rice at (a) $0 \%$ salt, (b) $2 \%$ salt, (c) $3 \%$ salt, (d) $3.5 \%$ salt and (e) $4 \%$ salt. 
increased with increasing EMC at constant temperature. These changes in EMC are due to the inability of the food to maintain vapour pressure at unity with decreasing moisture content. As moisture content decreased, moisture in the food tend to show a lower vapour pressure, acting as if in solution, changing with atmospheric humidity. These changes in vapour pressure in the food with atmospheric humidity result in the characteristic sigmoid shape of water sorption isotherms [10]. The isotherm presented a sigmoid shape (Type II according to BET classification) which is common for most of the hygroscopic foods. Sorptive behaviour depends on the temperature, it is decreasing with increasing temperature due to the activation of water molecules, at higher temperatures causes them to break away from the water binding sites, thus lowering the equilibrium moisture content [9] these results were compared with various researchers [14,15,28-30]. Effect of salt concentration on moisture sorption isotherm of preconditioned brown rice sample is shown in Figure 2. Where the water activity is seen to decreases with increasing salt concentration due to the ability of sodium and chloride ions to associate with water molecules $[31,32]$. These results are compared with the effect of salt and glucose concentration on water activity is explained by Martin Chaplin [33].

\section{Fitting sorption models to experimental sorption data}

The model coefficients and corresponding statistical results for the sorption models are listed in Tables 2-4. The goodness of fit was evaluated by using higher values of $\mathrm{R}^{2}$ and lowest values of RMSE and reduced- $\chi^{2}$. The average coefficients of determination $\left(R^{2}\right)$ in all cases were greater than 0.940 , the RMSE $\leq 2.152$ and the Reduced $-\chi^{2} \leq 4.629$. Among six models MGAB, MHEE and MOSE models gave better curve fitting compared to other models at all temperatures throughout the entire range of water activity. Least RMSE and reduced- $\chi^{2}$ values were obtained in case of GAB model and maximum RMSE and reduced- $\chi^{2}$ values were obtained in case of MHAE model over the temperature and salt concentration range. MGAB model gave the least value of RMSE and reduced- $\chi^{2}$ and higher value of $\mathrm{R}^{2}$ was considered the best model in case of all samples and MHAE gave the poor fitting results. The goodness of fit has been reported by several authors studying sorption behaviour of different food materials, GAB, BET and Halsey models [34] for blue berry, GAB model [21] for dent corn, GAB model [35] for capsicum, Modified Oswin [36] for millet, Strohman-Yoerger equation [13] for rice and Modified GAB [14] for rice.

\section{Net isosteric heat of sorption and sorption entropy}

Net isostericheat of sorption and sorption entropy of preconditioned brown rice were determined by using Clausius-Clapeyron equation (Equation 3) to the experimental equilibrium isotherm data. The isosteric heat of sorption is strong moisture dependent. The net isosteric heat of sorption decreased with increasing moisture content is shown in Figure 3. It is due to the fact that sorption initially occurs on the most active primary sites giving rise to higher exothermic interaction energies than those released when these sites become occupied [21]. Similar trends have been reported for isosteric heat of sorption of jasmine rice crackers [11], rough rice [14], rice [10,30], potato [37]. It is depicted from Figure 3, Isosteric heat of sorption increased with increasing salt concentration. This confirms the fact that at higher salt concentrations, the strength of water binding increases. Most of the authors described the relation between $\mathrm{Q}_{\mathrm{s}}$ and $\mathrm{M}_{\mathrm{e}}$ the model constants and stastical data of models suggested by Tsami et al. [38] and Kechau and Maalej [20] were shown in Table 5, from these results, it can be revealed that Kechau and Maalej [20] model gave the best relationship between $\mathrm{Q}_{\mathrm{st}}$ and $\mathrm{M}_{\mathrm{e}}$. Some more others express relations between $\mathrm{Qst}$
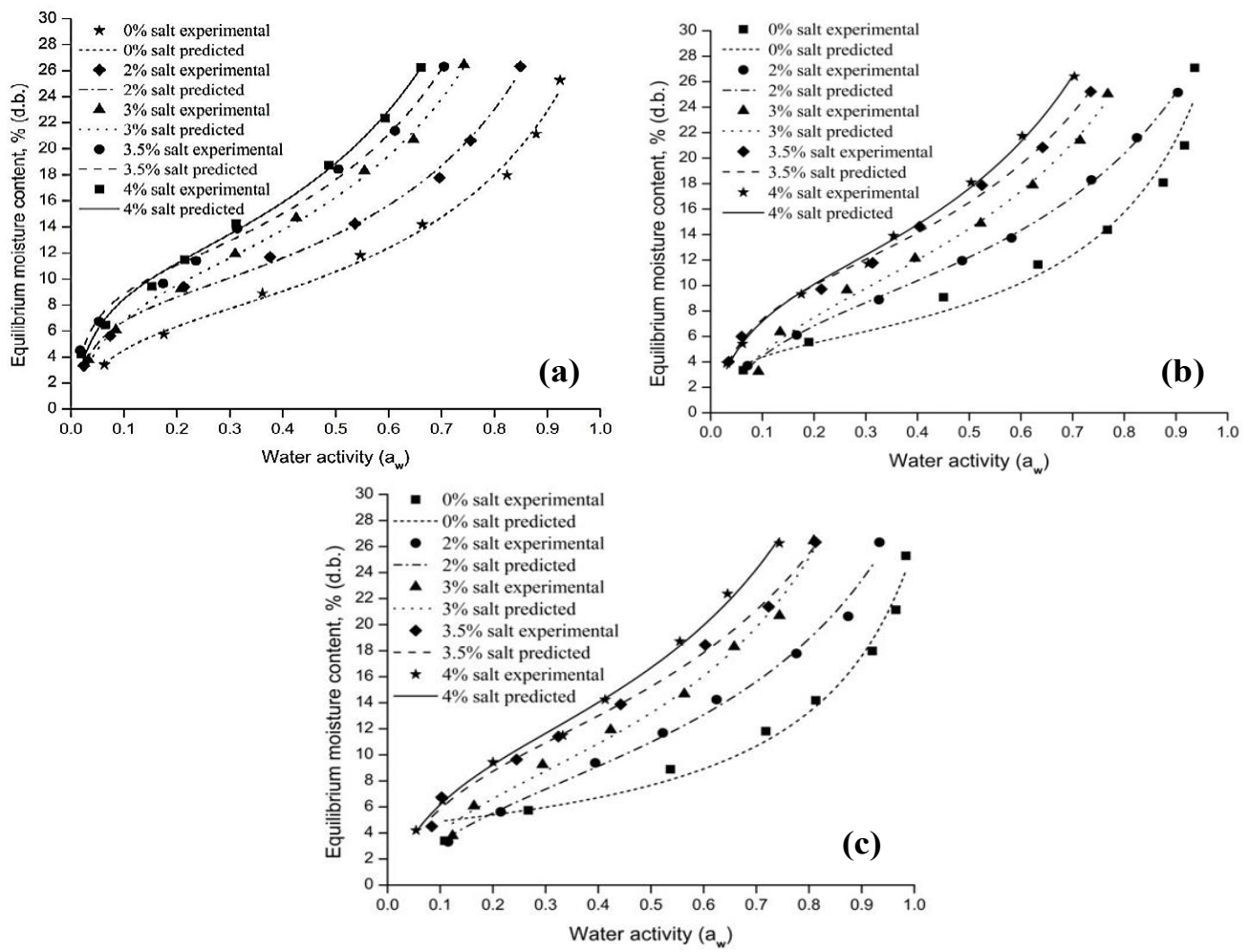

Figure 2: Effect of salt concentration on moisture sorption isotherm of pre conditioned pressure parboiled rice at (a) $20 \pm 1^{\circ} \mathrm{C},(\mathrm{b}) 25 \pm 1^{\circ} \mathrm{C}$ and (c) $30 \pm 1^{\circ} \mathrm{C}$. 
Citation: Naveen Kumar M, Das SK (2015) Moisture Sorption Isotherm of Preconditioned Pressure Parboiled Brown Rice. J Food Process Technol 6: 519. doi:10.4172/2157-7110.1000519

Page 5 of 9

\begin{tabular}{|c|c|c|c|c|c|c|}
\hline Models & & $0 \%$ salt & $2 \%$ salt & $3 \%$ salt & $3.5 \%$ salt & $4 \%$ salt \\
\hline \multirow{6}{*}{ MGAB } & A & 7.037 & 8.403 & 10.153 & 10.197 & 10.911 \\
\hline & B & 0.778 & 0.802 & 0.844 & 0.880 & 0.901 \\
\hline & C & 345.825 & 646.899 & 346.239 & 782.635 & 482.052 \\
\hline & Reduced $-x^{2}$ & 0.490 & 0.294 & 0.216 & 0.457 & 0.325 \\
\hline & $\mathrm{R}^{2}$ & 0.994 & 0.997 & 0.997 & 0.994 & 0.996 \\
\hline & RMSE & 0.700 & 0.542 & 0.465 & 0.676 & 0.570 \\
\hline \multirow{6}{*}{ MCPE } & A & 454.796 & 501.715 & 431.728 & 529.803 & 436.290 \\
\hline & B & 81.135 & 69.692 & 72.185 & 68.967 & 62.001 \\
\hline & C & 0.167 & 0.144 & 0.111 & 0.115 & 0.103 \\
\hline & Reduced $-x^{2}$ & 0.436 & 1.292 & 1.079 & 1.352 & 1.037 \\
\hline & $R^{2}$ & 0.995 & 0.985 & 0.987 & 0.983 & 0.988 \\
\hline & RMSE & 0.660 & 1.137 & 1.039 & 1.163 & 1.018 \\
\hline \multirow{6}{*}{ MOSE } & A & -4.178 & 12.300 & 13.774 & 15.221 & 15.254 \\
\hline & B & 0.741 & 0.075 & 0.139 & 0.161 & 0.213 \\
\hline & C & 2.868 & 2.759 & 2.332 & 2.618 & 2.414 \\
\hline & Reduced $-x^{2}$ & 0.319 & 0.365 & 0.169 & 0.375 & 0.163 \\
\hline & $\mathrm{R}^{2}$ & 0.996 & 0.996 & 0.998 & 0.995 & 0.998 \\
\hline & RMSE & 0.565 & 0.604 & 0.411 & 0.613 & 0.404 \\
\hline \multirow{6}{*}{ MHEE } & $A\left(\times 10^{-5}\right)$ & 7.097 & 4.096 & 4.527 & 2.403 & 2.839 \\
\hline & B & 142.230 & 71.128 & 81.860 & 44.102 & 51.351 \\
\hline & C & 1.700 & 1.948 & 1.762 & 2.075 & 1.949 \\
\hline & Reduced $-x^{2}$ & 0.719 & 1.890 & 0.815 & 1.340 & 0.717 \\
\hline & $R^{2}$ & 0.991 & 0.978 & 0.990 & 0.983 & 0.992 \\
\hline & RMSE & 0.848 & 1.375 & 0.903 & 1.158 & 0.847 \\
\hline \multirow{6}{*}{ MHAE } & A & 6.945 & 6.647 & 6.138 & 6.323 & 6.092 \\
\hline & B & -0.099 & -0.103 & -0.113 & -0.104 & -0.110 \\
\hline & C & 2.302 & 1.945 & 1.543 & 1.611 & 1.451 \\
\hline & Reduced $-x^{2}$ & 1.959 & 1.535 & 1.378 & 0.859 & 1.041 \\
\hline & $R^{2}$ & 0.976 & 0.982 & 0.983 & 0.989 & 0.988 \\
\hline & RMSE & 1.400 & 1.239 & 1.174 & 0.927 & 1.020 \\
\hline \multirow{6}{*}{ GAB } & $m_{0}$ & 0.070 & 0.082 & 0.100 & 0.102 & 0.106 \\
\hline & c & 17.291 & 17.311 & 24.100 & 39.130 & 39.132 \\
\hline & $\mathrm{k}$ & 0.778 & 0.811 & 0.849 & 0.880 & 0.916 \\
\hline & $\begin{array}{l}\text { Reduced } \\
-x^{2}\left(\times 10^{-5}\right)\end{array}$ & 4.904 & 16.580 & 5.716 & 4.574 & 9.239 \\
\hline & $\mathrm{R}^{2}$ & 0.994 & 0.980 & 0.993 & 0.994 & 0.989 \\
\hline & RMSE & 0.007 & 0.013 & 0.008 & 0.007 & 0.010 \\
\hline
\end{tabular}

Table 2: Estimated parameters of preconditioned pressure parboiled rice at different salt concentration solutions for different isotherm models at $20^{\circ} \mathrm{C}$

and Me for different food materials, power function [9] for potato, exponential function for onions and exponential form [17] for rough rice.

The entropy of sorption of preconditioned pressure parboiled brown rice as a function of moisture content is shown in Figure 4, from this figure it can be observed that entropy of sorption decreased with increasing moisture content, similar trends have been reported for differential entropy of starch powders [39], pepper [40], crushed chillies [8] but for rice stored under controlled humidity chamber reported that sorption entropy decreased with increasing moisture content in desorption process but in adsorption process increased up to certain moisture content later it decreased with increasing moisture content [10]. Differential entropy increased with increasing salt concentration (Figure 4) from this we can reveal that number of sorption sites were more at higher salt concentration at a specific energy level. The $\Delta S$ versus $M_{e}$ results are adequately represented by a exponential relation as represented by the equation

$$
\begin{aligned}
& 0 \% \text { salt } \Delta \mathrm{S}=0.307 \mathrm{e}^{-0.134 \mathrm{Me}} \quad \mathrm{R}^{2}=0.994 \\
& 2 \% \text { salt } \Delta \mathrm{S}=0.919 \mathrm{e}^{-0.214 \mathrm{Me}} \quad \mathrm{R}^{2}=0.978 \\
& 3 \% \text { salt } \Delta S=0.392 \mathrm{e}^{-0.130 \mathrm{Me}} \quad \mathrm{R}^{2}=0.993 \\
& 3.5 \% \text { salt } \Delta \mathrm{S}=0.504 \mathrm{e}^{-0.156 \mathrm{Me}} \mathrm{R}^{2}=0.957 \\
& 4 \% \text { salt } \Delta \mathrm{S}=0.345 \mathrm{e}^{-0.110 \mathrm{Me}} \quad \mathrm{R}^{2}=0.984
\end{aligned}
$$

Many authors describe a relation between $\Delta S$ and $M_{e}$ power function [9] for potato, exponential form [26] for Mexican mennonitestyle cheese and exponential [39] for the starch powders.

\section{Net integral enthalpy and entropy}

Net integral enthalpy given by Equation 9, the experimental

\begin{tabular}{|c|c|c|c|c|c|c|}
\hline Models & & $0 \%$ salt & $2 \%$ salt & $3 \%$ salt & $3.5 \%$ salt & $4 \%$ salt \\
\hline \multirow{6}{*}{ MGAB } & A & 5.100 & 9.005 & 10.285 & 10.510 & 10.724 \\
\hline & B & 0.849 & 0.732 & 0.796 & 0.814 & 0.871 \\
\hline & C & 700.000 & 267.807 & 208.718 & 506.351 & 413.963 \\
\hline & Reduced- $x^{2}$ & 2.843 & 0.052 & 0.555 & 0.288 & 0.247 \\
\hline & $\mathrm{R}^{2}$ & 0.969 & 0.999 & 0.993 & 0.996 & 0.997 \\
\hline & RMSE & 1.686 & 0.228 & 0.745 & 0.537 & 0.497 \\
\hline \multirow{6}{*}{ MCPE } & A & 443.457 & 455.305 & 389.890 & 99.419 & 420.237 \\
\hline & B & 83.842 & 78.834 & 82.662 & -5.570 & 65.252 \\
\hline & C & 0.175 & 0.148 & 0.110 & 0.116 & 0.103 \\
\hline & Reduced- $x^{2}$ & 3.857 & 0.170 & 0.823 & 0.679 & 1.252 \\
\hline & $\mathrm{R}^{2}$ & 0.957 & 0.998 & 0.989 & 0.991 & 0.986 \\
\hline & RMSE & 1.964 & 0.413 & 0.907 & 0.824 & 1.119 \\
\hline \multirow{6}{*}{ MOSE } & A & -7.394 & 11.221 & 12.368 & 14.113 & 13.978 \\
\hline & B & 0.664 & 0.029 & 0.075 & 0.105 & 0.159 \\
\hline & C & 2.669 & 2.821 & 2.145 & 2.485 & 2.237 \\
\hline & Reduced- $x^{2}$ & 1.536 & 1.111 & 0.799 & 0.195 & 0.137 \\
\hline & $\mathrm{R}^{2}$ & 0.983 & 0.986 & 0.990 & 0.997 & 0.998 \\
\hline & RMSE & 1.239 & 1.054 & 0.894 & 0.442 & 0.370 \\
\hline \multirow{6}{*}{ MHEE } & $A\left(\times 10^{-5)}\right.$ & 10.140 & 6.153 & 6.664 & 3.307 & 4.054 \\
\hline & B & 213.857 & 119.535 & 133.194 & 68.685 & 83.617 \\
\hline & C & 1.492 & 1.727 & 1.550 & 1.897 & 1.733 \\
\hline & Reduced- $x^{2}$ & 4.115 & 0.138 & 0.886 & 0.612 & 0.706 \\
\hline & $\mathrm{R}^{2}$ & 0.954 & 0.998 & 0.989 & 0.992 & 0.992 \\
\hline & RMSE & 2.029 & 0.371 & 0.941 & 0.782 & 0.840 \\
\hline \multirow{6}{*}{ MHAE } & A & 6.916 & 7.136 & 6.235 & 6.502 & 6.244 \\
\hline & B & -0.100 & -0.082 & -0.107 & -0.096 & -0.102 \\
\hline & C & 2.193 & 2.235 & 1.513 & 1.619 & 1.430 \\
\hline & Reduced- $x^{2}$ & 1.819 & 3.730 & 2.116 & 1.672 & 1.413 \\
\hline & $\mathrm{R}^{2}$ & 0.980 & 0.953 & 0.973 & 0.978 & 0.984 \\
\hline & RMSE & 1.349 & 1.931 & 1.455 & 1.293 & 1.189 \\
\hline \multirow{6}{*}{ GAB } & $\mathrm{m}_{0}$ & 0.042 & 0.091 & 0.100 & 0.109 & 0.107 \\
\hline & c & 7.827 & 9.349 & 10.712 & 16.559 & 20.254 \\
\hline & k & 0.883 & 0.728 & 0.806 & 0.798 & 0.874 \\
\hline & $\begin{array}{l}\text { Reduced } \\
-x^{2}\left(\times 10^{-5}\right)\end{array}$ & 94.920 & 1.062 & 8.350 & 3.684 & 4.194 \\
\hline & $\mathrm{R}^{2}$ & 0.895 & 0.999 & 0.989 & 0.995 & 0.995 \\
\hline & RMSE & 0.031 & 0.003 & 0.009 & 0.006 & 0.006 \\
\hline
\end{tabular}
sorption data were first represented in the form of spreading pressure isotherm. Spreading pressure values were calculated using Eq. 8 the constants $\mathrm{C}_{\mathrm{G}}$ and $\mathrm{K}_{\mathrm{G}}$ were determined from the $\mathrm{GAB}$ equation (Table 1). Spreading pressure increased with increasing water activity and salt

Table 3: Estimated parameters of preconditioned pressure parboiled rice at different salt concentration solutions for different isotherm models at $25^{\circ} \mathrm{C}$. 
Citation: Naveen Kumar M, Das SK (2015) Moisture Sorption Isotherm of Preconditioned Pressure Parboiled Brown Rice. J Food Process Technol 6: 519. doi:10.4172/2157-7110.1000519

Page 6 of 9

\begin{tabular}{|c|c|c|c|c|c|c|}
\hline Models & & $0 \%$ salt & $2 \%$ salt & $3 \%$ salt & $3.5 \%$ salt & $4 \%$ salt \\
\hline \multirow{6}{*}{ MGAB } & $A$ & 4.966 & 8.825 & 9.322 & 10.881 & 11.150 \\
\hline & $B$ & 0.807 & 0.723 & 0.817 & 0.744 & 0.812 \\
\hline & C & 688.789 & 204.869 & 225.580 & 370.829 & 351.994 \\
\hline & Reduced $-x^{2}$ & 0.975 & 0.769 & 0.734 & 0.374 & 0.319 \\
\hline & $\mathrm{R}^{2}$ & 0.988 & 0.991 & 0.991 & 0.995 & 0.996 \\
\hline & RMSE & 0.987 & 0.877 & 0.857 & 0.612 & 0.565 \\
\hline \multirow{6}{*}{ MCPE } & $A$ & 495.111 & 434.463 & 377.374 & 76.310 & 410.615 \\
\hline & B & 72.002 & 83.955 & 86.273 & -13.109 & 67.366 \\
\hline & $\mathrm{C}$ & 0.228 & 0.154 & 0.110 & 0.120 & 0.104 \\
\hline & Reduced $-x^{2}$ & 0.076 & 0.401 & 1.169 & 0.465 & 0.847 \\
\hline & $\mathrm{R}^{2}$ & 0.999 & 0.995 & 0.986 & 0.994 & 0.990 \\
\hline & RMSE & 0.275 & 0.633 & 1.081 & 0.682 & 0.921 \\
\hline \multirow{6}{*}{ MOSE } & $A$ & -10.107 & 10.470 & 11.532 & 12.972 & 12.828 \\
\hline & B & 0.630 & 0.009 & 0.051 & 0.066 & 0.128 \\
\hline & $\mathrm{C}$ & 3.770 & 2.870 & 2.092 & 2.548 & 2.245 \\
\hline & Reduced $-x^{2}$ & 1.530 & 1.971 & 0.818 & 0.581 & 0.342 \\
\hline & $\mathrm{R}^{2}$ & 0.981 & 0.977 & 0.990 & 0.993 & 0.996 \\
\hline & RMSE & 1.237 & 1.404 & 0.904 & 0.762 & 0.585 \\
\hline \multirow{6}{*}{ MHEE } & $A\left(\times 10^{-5}\right)$ & 8.955 & 7.544 & 8.033 & 3.996 & 4.527 \\
\hline & B & 187.440 & 156.616 & 170.688 & 89.839 & 98.821 \\
\hline & C & 1.675 & 1.620 & 1.437 & 1.806 & 1.675 \\
\hline & Reduced $-x^{2}$ & 0.307 & 0.472 & 1.095 & 0.556 & 0.560 \\
\hline & $\mathrm{R}^{2}$ & 0.996 & 0.994 & 0.987 & 0.993 & 0.993 \\
\hline & RMSE & 0.554 & 0.687 & 1.046 & 0.746 & 0.749 \\
\hline \multirow{6}{*}{ MHAE } & $A$ & 8.427 & 7.462 & 6.470 & 6.930 & 6.560 \\
\hline & B & -0.050 & -0.074 & -0.098 & -0.082 & -0.091 \\
\hline & C & 3.372 & 2.387 & 1.550 & 1.826 & 1.518 \\
\hline & Reduced $-x^{2}$ & 3.609 & 4.629 & 1.944 & 2.327 & 1.864 \\
\hline & $\mathrm{R}^{2}$ & 0.955 & 0.945 & 0.976 & 0.971 & 0.978 \\
\hline & RMSE & 1.900 & 2.152 & 1.394 & 1.526 & 1.365 \\
\hline \multirow{6}{*}{ GAB } & $m_{\circ}$ & 0.049 & 0.087 & 0.093 & 0.109 & 0.111 \\
\hline & c & 6.742 & 7.219 & 7.519 & 11.733 & 12.361 \\
\hline & $\mathrm{k}$ & 0.810 & 0.727 & 0.817 & 0.744 & 0.812 \\
\hline & Reduced $-x^{2}\left(\times 10^{-5}\right)$ & 30.358 & 7.728 & 7.344 & 3.974 & 3.376 \\
\hline & $\mathrm{R}^{2}$ & 0.962 & 0.991 & 0.991 & 0.995 & 0.996 \\
\hline & RMSE & 0.017 & 0.009 & 0.009 & 0.006 & 0.006 \\
\hline
\end{tabular}

Table 4: Estimated parameters of preconditioned pressure parboiled rice at different salt concentration solutions for different isotherm models at $30^{\circ} \mathrm{C}$.
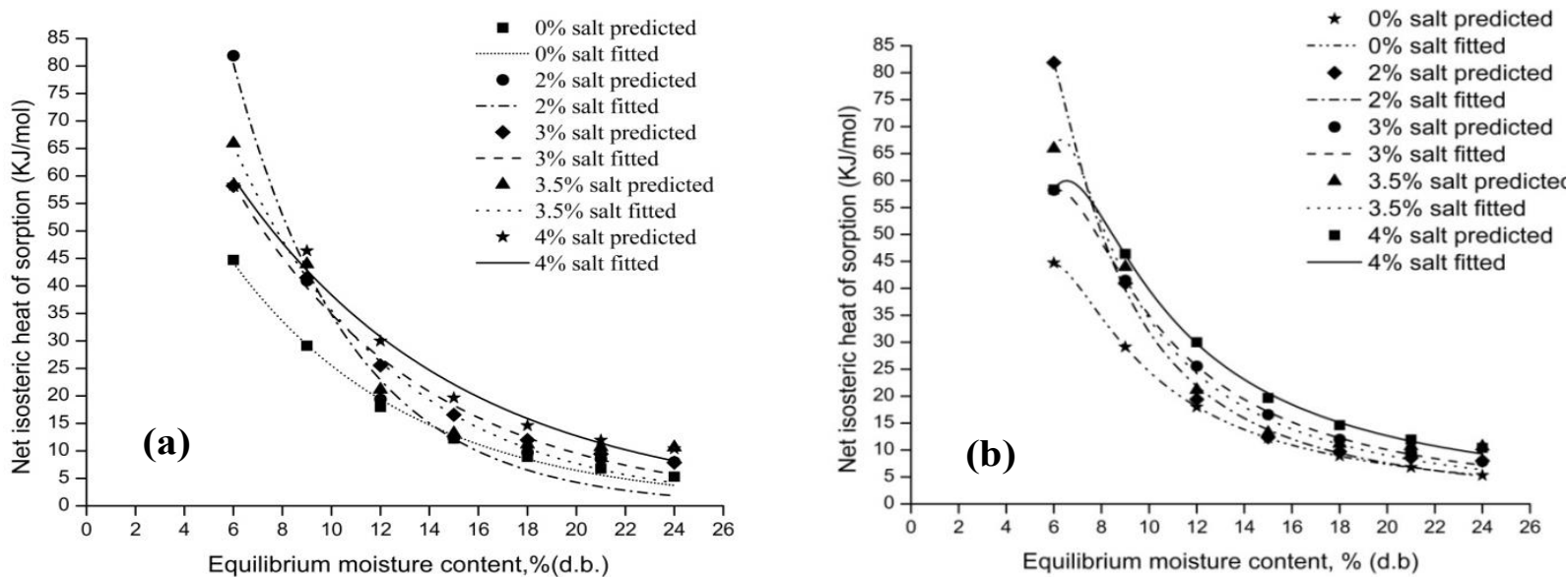

Figure 3: Net isosteric heat of sorption of preconditioned pressure parboiled brown rice at different salt concentrations fitted with (a) Tsami et al. model (b) Kechau and Maalej model. 
Citation: Naveen Kumar M, Das SK (2015) Moisture Sorption Isotherm of Preconditioned Pressure Parboiled Brown Rice. J Food Process Technol 6: 519. doi:10.4172/2157-7110.1000519

Page 7 of 9

\begin{tabular}{|c|c|c|c|c|c|c|}
\hline Models & & $0 \%$ salt & $2 \%$ salt & $3 \%$ salt & $3.5 \%$ salt & $4 \%$ salt \\
\hline \multirow{7}{*}{$\begin{array}{l}\text { Kechau and } \\
\text { Maalej [24] }\end{array}$} & $a$ & 1470.814 & 3830.65 & 2625.3 & 2949.984 & 2044.665 \\
\hline & $\mathrm{b}$ & 3.884 & 6.552 & 3.371 & 8.539 & 4.162 \\
\hline & c & 9614.959 & 675433.616 & 7235.502 & 56946200 & 24450.6 \\
\hline & $d$ & 5.652 & 8.63 & 5.228 & 10.471 & 5.859 \\
\hline & Reduced- $x^{2}$ & 0.003 & 6.907 & 0.309 & 14.766 & 0.833 \\
\hline & $\mathrm{R}^{2}$ & 1 & 0.995 & 1 & 0.984 & 0.999 \\
\hline & RMSE & 0.058 & 2.628 & 0.555 & 3.843 & 0.913 \\
\hline \multirow[t]{5}{*}{ Tsami et al. [44] } & $Q_{0}$ & 100.769 & 282.688 & 127.133 & 164.095 & 115.55 \\
\hline & $\mathrm{M}_{\mathrm{r}}$ & 7.282 & 4.775 & 7.734 & 6.542 & 9.072 \\
\hline & Reduced- $x^{2}$ & 1.326 & 18.354 & 2.817 & 20.404 & 5.551 \\
\hline & $\mathrm{R}^{2}$ & 0.995 & 0.979 & 0.993 & 0.963 & 0.987 \\
\hline & RMSE & 1.151 & 4.284 & 1.678 & 4.517 & 2.356 \\
\hline
\end{tabular}

Table 5: Fitted parameters of net isosteric heat of sorption versus equilibrium moisture content for different models.

\begin{tabular}{|c|c|c|c|c|c|c|c|c|c|c|c|c|c|c|c|}
\hline \multirow[t]{2}{*}{ aw } & \multicolumn{3}{|c|}{$0 \%$ salt } & \multicolumn{3}{|c|}{$2 \%$ salt } & \multicolumn{3}{|c|}{$3 \%$ salt } & \multicolumn{3}{|c|}{$3.5 \%$ salt } & \multicolumn{3}{|c|}{$4 \%$ salt } \\
\hline & $20^{\circ} \mathrm{C}$ & $25^{\circ} \mathrm{C}$ & $30^{\circ} \mathrm{C}$ & $20^{\circ} \mathrm{C}$ & $25^{\circ} \mathrm{C}$ & $30^{\circ} \mathrm{C}$ & $20^{\circ} \mathrm{C}$ & $25^{\circ} \mathrm{C}$ & $30^{\circ} \mathrm{C}$ & $20^{\circ} \mathrm{C}$ & $25^{\circ} \mathrm{C}$ & $30^{\circ} \mathrm{C}$ & $20^{\circ} \mathrm{C}$ & $25^{\circ} \mathrm{C}$ & $30^{\circ} \mathrm{C}$ \\
\hline 0.100 & 0.034 & 0.022 & 0.018 & 0.035 & 0.021 & 0.018 & 0.045 & 0.026 & 0.020 & 0.060 & 0.035 & 0.026 & 0.061 & 0.042 & 0.029 \\
\hline 0.200 & 0.055 & 0.038 & 0.033 & 0.056 & 0.037 & 0.032 & 0.068 & 0.043 & 0.036 & 0.085 & 0.055 & 0.044 & 0.087 & 0.065 & 0.048 \\
\hline 0.300 & 0.070 & 0.052 & 0.046 & 0.072 & 0.050 & 0.044 & 0.085 & 0.058 & 0.049 & 0.103 & 0.071 & 0.058 & 0.105 & 0.082 & 0.063 \\
\hline 0.400 & 0.083 & 0.065 & 0.057 & 0.085 & 0.061 & 0.054 & 0.099 & 0.070 & 0.061 & 0.118 & 0.084 & 0.071 & 0.121 & 0.096 & 0.077 \\
\hline 0.500 & 0.095 & 0.077 & 0.068 & 0.097 & 0.072 & 0.065 & 0.112 & 0.082 & 0.072 & 0.132 & 0.096 & 0.082 & 0.135 & 0.109 & 0.089 \\
\hline 0.600 & 0.106 & 0.089 & 0.079 & 0.109 & 0.082 & 0.074 & 0.124 & 0.093 & 0.083 & 0.145 & 0.108 & 0.093 & 0.148 & 0.122 & 0.100 \\
\hline 0.700 & 0.117 & 0.102 & 0.090 & 0.121 & 0.092 & 0.084 & 0.137 & 0.105 & 0.095 & 0.159 & 0.120 & 0.103 & 0.163 & 0.136 & 0.112 \\
\hline 0.800 & 0.129 & 0.116 & 0.102 & 0.133 & 0.102 & 0.095 & 0.151 & 0.117 & 0.107 & 0.173 & 0.132 & 0.115 & 0.179 & 0.150 & 0.125 \\
\hline 0.900 & 0.142 & 0.134 & 0.117 & 0.148 & 0.114 & 0.106 & 0.167 & 0.131 & 0.122 & 0.191 & 0.146 & 0.127 & 0.199 & 0.168 & 0.140 \\
\hline
\end{tabular}

Table 6: Effect of temperature and salt concentration on spreading pressure of pre conditioned brown rice at constant water activity.

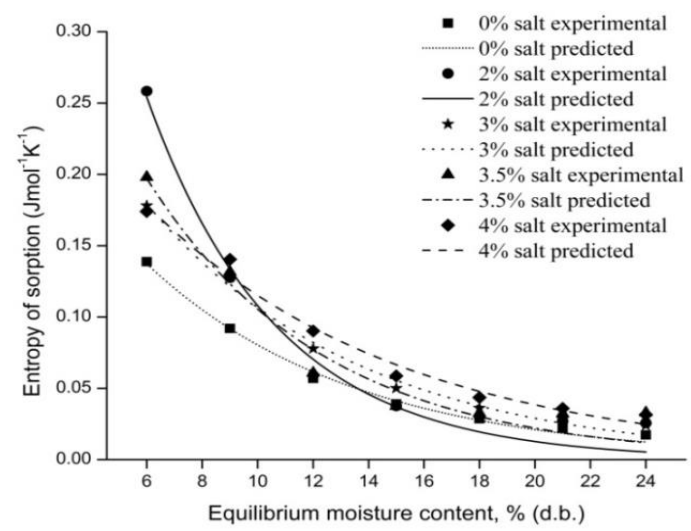

Figure 4: Entropy of sorption of preconditioned pressure parboiled brown rice at different salt concentrations fitted with exponential model.

concentration and decreased with increasing temperature at a specific water activity (Table 6). The trends of spreading pressure with respect to temperature and water activity are comparable with [41] starchy materials [42], cereal grains [10], rice and [39] starch powders.

Effect of moisture content on net integral enthalpy of preconditioned pressure parboiled brown rice is shown in Figure 5. This graph clearly shows that net integral enthalpy decreased with increasing moisture content. At low moisture contents, water is adsorbed on the most accessible locations on the exterior surface of the solid. The net integral enthalpy then starts to decline as less favourable locations are covered and multiple layers of sorbed water form [39]. Similar trends have been reported for integral enthalpy of rice [30], maize, rough rice

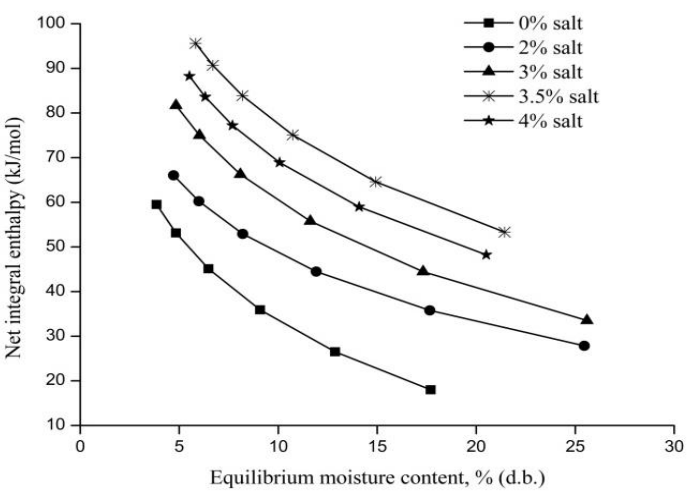

Figure 5: Net integral enthalpy of preconditioned pressure parboiled brown rice at different salt concentrations.

and wheat [42], rice [10] and for starch powders [39]. The Figure 5 shows the effect of salt concentration on spreading pressure from this graph we can reveal that integral enthalpy increased with increasing salt concentration up to $3.5 \%$ salt but in case of $4 \%$ salt treated sample integral enthalpy low as compared to $3.5 \%$ salt.

Net integral entropy of preconditioned brown rice was calculated by applying Equation (10). Net integral entropy increased with increasing moisture content shown in Figure 6. The net integral entropy negative in magnitude being low at low moisture content while increasing moisture content integral entropy moves towards 0 $\mathrm{kJ} / \mathrm{mol} \mathrm{K}$. The initial highly negative value of integral entropy at low moisture content was due to the first few percent of water is very tightly 


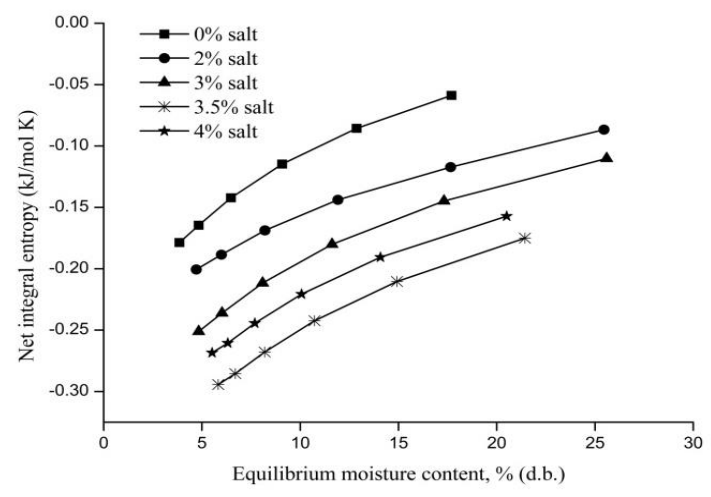

Figure 6: Net integral entropy of preconditioned pressure parboiled brown rice at different salt concentrations.

bound [39]. Similar trends were observed for integral entropy of starch powders [39], rice [10], potato [9] and cow pea [43]. Integral entropy decreased with increasing salt concentration (Figure 6) but in $4 \%$ salt treated sample net integral entropy high as compared to $3.5 \%$ salt treated sample.

\section{Conclusions}

On the basis of this work the following conclusion can be drawn. A non-linear regression analysis was used to evaluate the constants of the sorption models. The moisture sorption isotherm of preconditioned pressure parboiled brown rice at different salt concentrations adequately described by the MGAB equation. Net isosteric heat of sorption, calculated using the Clausis-Clapeyron equation. The model suggested by Kechau and Maalej gave the best relationship between net isosteric heat of sorption and equilibrium moisture content. Net isosteric heat of sorption decreased with increasing moisture content and increases with increasing salt concentration. Differential entropy of sorption can be characterised by an exponential model. Differential entropy decreased with increasing moisture content and increase with increasing salt concentration. Spreading pressure increased with increasing water activity and decrease with temperature. Net integral enthalpy decreased with increasing moisture content and increases with increasing salt concentration. Net integral entropy increased with increasing moisture content and decrease with increasing salt concentration.

\section{References}

1. FAO (1998) Rice in human nutrition.chap.6. Major processed rice products.

2. Chattopadhyay PK (2004) Post-harvest technology for rice in India: a changing scenario, Proceedings of the World Rice Research Conference held in Tokyo and Tsukuba, Japan, 4-7, November 2004. Los Banos, Philippines 294-296.

3. Narayanswamy CK (1956) The rice we eat. All India Khadi and Village Industries Board, Bombay, India.

4. Ghose RLM, Ghatge MB, Subrahmanyan, V (1960) Rice in India, revised edition. Indian Council of Agricultural Research, New Delhi, India.

5. Das H (2005) Food Processing Operation Analysis. Asian Books Private Limited, New Delhi, India.

6. Arya SS (1992) Convenience foods-emerging scenario. Indian Food Industry 11: $31-41$.

7. Chinnaswamy R, Bhattacharya KR (1983) Studies on expanded rice, optimum processing conditions. Journal of Food Science Technology 48: 1604-1608.

8. Arslan N, Togrul H (2005) Moisture Sorption Isotherms for Crushed Chillies Biosystems Engineering 90: 47-61.
9. McMinn WAM, Magee TRA (2003) Thermodynamic properties of moisture sorption of potato. Journal of Food Engineering 60: 157-165.

10. Togrul H, Arslan N (2006) Moisture sorption behaviour and thermodynamic characteristics of rice stored in a chamber under controlled humidity. Biosystems Engineering 95: 181-195.

11. Siripatrawan U, Jantawat $P(2006)$ Determination of Moisture Sorption Isotherms of Jasmine Rice Crackers Using BET and GAB Models. Food Science and Technology International 12: 459-465.

12. Rizvi SSH, Benado AL (1984) Thermodynamic properties of dehydrated foods Food Technology 38: 83-92.

13. Da-Wen Sun (1999) Comparison and selection of EMC/ERH isotherm equations for rice. Journal of Stored Products Research 35: 249-264.

14. Iguaz A, Virseda $P$ (2007) Moisture desorption isotherms of rough rice at high temperatures. Journal of Food Engineering 79: 794-802.

15. Basunia MA, Abe T (1999) Moisture adsorption isotherms of rough rice. Journal of Food Engineering 42: 235-242.

16. Ondier GO, Siebenmorgen TJ (2009) Equilibrium moisture contents of rough rice Dried using high-temperature, fluidized-bed conditions. BR Wells rice research studies; AAES research series.

17. Ondier GO, Siebenmorgen TJ, Mauromoustakos A (2011) Equilibrium moisture contents of rice kernel components. BR Wells rice research studies; AAES research series.

18. Tolaba MP, Peltzer M, Enriquez N, Pollio ML (2004) Grain sorption equilibria of quinoa grains. Journal of Food Engineering 61: 365-371.

19. Rizvi SSH (1986) Thermodynamic properties of food in dehydration. In: Rao MA and Rizvi SSH (Eds.). Engineering Properties of Foods. New York.

20. Kechau N, Maalej M (1999) Desorption isotherms of imported banana. Drying Technology 17: 1201-1213.

21. Samapundo S, Devlieghere F, Meuleneur B, Atukwase A, Lamboni Y, et al. (2007) Sorption isotherms and isosteric heat of sorption of whole yellow dent corn. Journal of Food Engineering 79: 168-175.

22. Fasina OO (2006) Thermodynamic properties of sweet potato. Journal of Food Eng 75: 149-155.

23. Liebanes MD, Aragon JM, Palancar MC, Arevalo G, Jimenez D, et al. (2006) Equilibrium moisture isotherms of two-phase solid olive oil byproducts: adsorption process thermodynamics. Colloid Surface 282: 298-306.

24. Noshad M, Shahidi F, Mohebbi M, Mortazavi S (2013) Desorption isotherms and thermodynamic properties of fresh and osmotic-ultrasonic dehydrated quince. Journal of Food Processing and Preservation 37: 381-390.

25. Fasina O, Ajibola OO, Tyler R (1999) Thermodynamics of moisture sorption of winged bean seed and Gari. Journal of Food Process Engineering 22: 405-418.

26. Sergio I, Monteagudo M, Fierro FS (2014) Moisture sorption isotherms and thermodynamic properties of mexican mennonite-style cheese. Journal of Food Science Technology 51: 2393-2403.

27. Mazza G, LeMaguer M (1978) Water sorption properties of yellow globe onion. Canadian Institute of Food Science and Technology 11: 189-193.

28. Aviara NA, Ajibolab OO, Aregbesolab OA, Adedejib MA (2006) Moisture sorption isotherms of sorghum malt at 40 and $50^{\circ} \mathrm{C}$. Journal of Stored Products Research 42: 290-301.

29. Al-Muhtaseb AH, McMinn WAM, Magee TRA (2004) Water sorption isotherm of starch powders Part 1: Mathematical description of experimental data Journal of Food Engineering 61: 297-307.

30. Benado AL, Rizvi SSH (1985) Thermodynamic Properties of Water on Rice as Calculated from Reversible and Irreversible Isotherms. Journal of Food Science 50: 101-105.

31. Fennema OR (1996) Food chemistry. 3rd ed. New York: Marcel Dekker

32. Potter NN, Hotchkiss JH (1998) Food science. Food science texts series. 5th ed. New York: Chapman and Hall.

33. Martin Chaplin (2015) Water structure and science, chapter: water activity.

34. Vega-Galvez A, Lopez J, Miranda M, Scala KD, Yagnam F, et al. (2009) Mathematical modelling of moisture sorption isotherms and determination of 
Citation: Naveen Kumar M, Das SK (2015) Moisture Sorption Isotherm of Preconditioned Pressure Parboiled Brown Rice. J Food Process Technol 6: 519. doi:10.4172/2157-7110.1000519

Page 9 of 9

isosteric heat of blueberry variety O'Neil. International Journal of Food Science and Technology 44: 2033-2041.

35. Akin A, Ozbalta N, Gungor A (2009) Equilibrium moisture content and equations for fitting sorption isotherms of capsicum annuum. GIDA 34: 205-211.

36. Rajia AO, Ojediranb JO (2011) Moisture sorption isotherms of two varieties of millet. Food and Biproducts Processing 89: 178-184.

37. Wang N, Brennan JG (1991) Moisture Sorption Isotherm Characteristics of Potatoes at Four Temperatures. Journal of Food Engineering 14: 269-287.

38. Tsami E, Marinos-Kouris D, Maroulis ZB (1990) Water sorption isotherms of raisins, currants, figs, prunes and apricots. Journal of Food Science 55: 15941597.

39. Al-Muhtaseb AH, McMinn WAM, Magee TRA (2004b) Water sorption isotherms of starch powders. Part 2: Thermodynamic characteristics. Journal of Food Engineering 62: 135-142.

40. Kaymak-Ertekin F, Sultanoglu M (2001) Moisture sorption isotherm characteristics of peppers. Journal of Food Engineering 47: 225-231.

41. Tolaba MP, Suarez C, Viollaz P (1995) Spreading pressure water activity and moisture relationships in starchy materials. Drying Technology 13: 2097-2111.

42. Tolaba MP, Suarez C, Viollaz P (1997) Heats and entropies of sorption of cereal grains: A comparison between integral and differential quantities. Drying Technology 15: 137-150.

43. Ajibola OO, Aviara NA, Ajetumobi OE (2003) Sorption equilibrium and thermodynamic properties of cowpea (Vigna unguiculata). Journal of Food Engineering 58: 317-324. 